\title{
Reduction of propargylic sulfones to $(Z)$-allylic sulfones using zinc and ammonium chloride
}

\author{
Helen M. Sheldrake and Timothy W. Wallace* \\ School of Chemistry, The University of Manchester, Oxford Road, Manchester M13 9PL, UK
}

Received 23 January 2007; revised 13 April 2007; accepted 17 April 2007

Available online 25 April 2007

\begin{abstract}
Propargylic sulfones can be cis-hydrogenated using commercial zinc powder and ammonium chloride in THF-water at room temperature, the major products being the corresponding $(Z)$-allylic sulfones. Other reducible groups (alkene, benzyloxy) are not affected. Allenylsulfones are implicated in one of the possible reaction pathways.
\end{abstract}

(c) 2007 Elsevier Ltd. All rights reserved.

The partial hydrogenation of the alkyne bond of a propargylic sulfone $\mathbf{1}$ (Scheme 1) is a potentially valuable process. The derived allylic sulfones 2 are useful intermediates, with applications in the Julia olefination reaction, ${ }^{1}$ various sequences involving metallation and reaction with electrophiles, ${ }^{2}$ radical processes ${ }^{3}$ and cyclisations. ${ }^{4}$ Published routes to allylic sulfones include the base-induced isomerisation of vinylic sulfones, ${ }^{5}$ the addition of nucleophiles to alka-1,3-dienylsulfones, ${ }^{6}$ $\mathrm{C}-\mathrm{S}$ coupling reactions, ${ }^{7}$ regioselective additions to 1,2-allenylsulfones ${ }^{8}$ and diverse rearrangements. ${ }^{9}$ The sequence in Scheme 1 offers a simple and convergent route to such compounds from readily available thioethers $3{ }^{10}$

Surprisingly few examples of the reduction of propargylic sulfones to allylic sulfones are documented in the literature, ${ }^{11,12}$ the simple cases involving hydrogenation over Lindlar catalyst and proceeding with the expected $(Z)$-selectivity. ${ }^{11}$ In the wider context, several groups have described the reduction of other types of alkyne to alkenes using different forms of zinc, including zinccopper couple, ${ }^{13} \mathrm{Zn}$ powder activated with 1,2-dibromoethane, ${ }^{14}$ Rieke zinc ${ }^{15,16}$ and zinc powder produced by a combination of electroreduction and ultrasonication. ${ }^{17}$ The reactivity and chemoselectivity of these different forms of zinc can vary considerably, but the $(Z)$-alkene generally predominates when a disub-

$\overline{\text { Keywords: }}$ Propargylic sulfone; Allylsulfone; cis-Hydrogenation; Reduction; Zinc.

* Corresponding author. Fax: +44 (0) 161275 4598; e-mail: tim.wallace@manchester.ac.uk

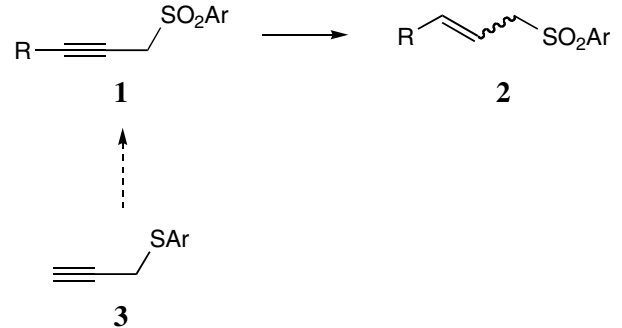

Scheme 1.

stituted alkyne is reduced under non-acidic conditions. Our interest in this subject led us to investigate the hitherto unexamined combination of propargylic sulfones with zinc and we herein describe our results, which indicate that for some substrates the cis-hydrogenation of the alkyne bond can be conveniently brought about with an excess of commercial zinc powder and ammonium chloride in $\mathrm{THF}$-water at room temperature.

The results of a series of reductions of sulfones are shown in Table $1 .^{18-20}$ The reduction of the parent system 4 to the allyl sulfone $\mathbf{5}$ proceeded smoothly using a large excess of zinc, although in later experiments it was established that 5 mol. equiv was sufficient for this particular substrate (vide infra). A methyl or phenyl substituent on the alkyne (entries 2,3) appeared to inhibit the reaction, with significant amounts of starting materials $\mathbf{6}$ and $\mathbf{8}$ remaining unreacted, but the preference for the formation of the respective $(Z)$-alkenyl sulfones 7 and 9 was evident. The reduction of sulfone $\mathbf{8}$ also gave rise to significant quantities of a third product which was identified as allenic sulfone $\mathbf{1 1}$ on the basis of 
Table 1. Reductions of alkynyl and allenyl sulfones with $\mathrm{Zn}^{18}$ and $\mathrm{NH}_{4} \mathrm{Cl}$ in water-THF ${ }^{19,20}$

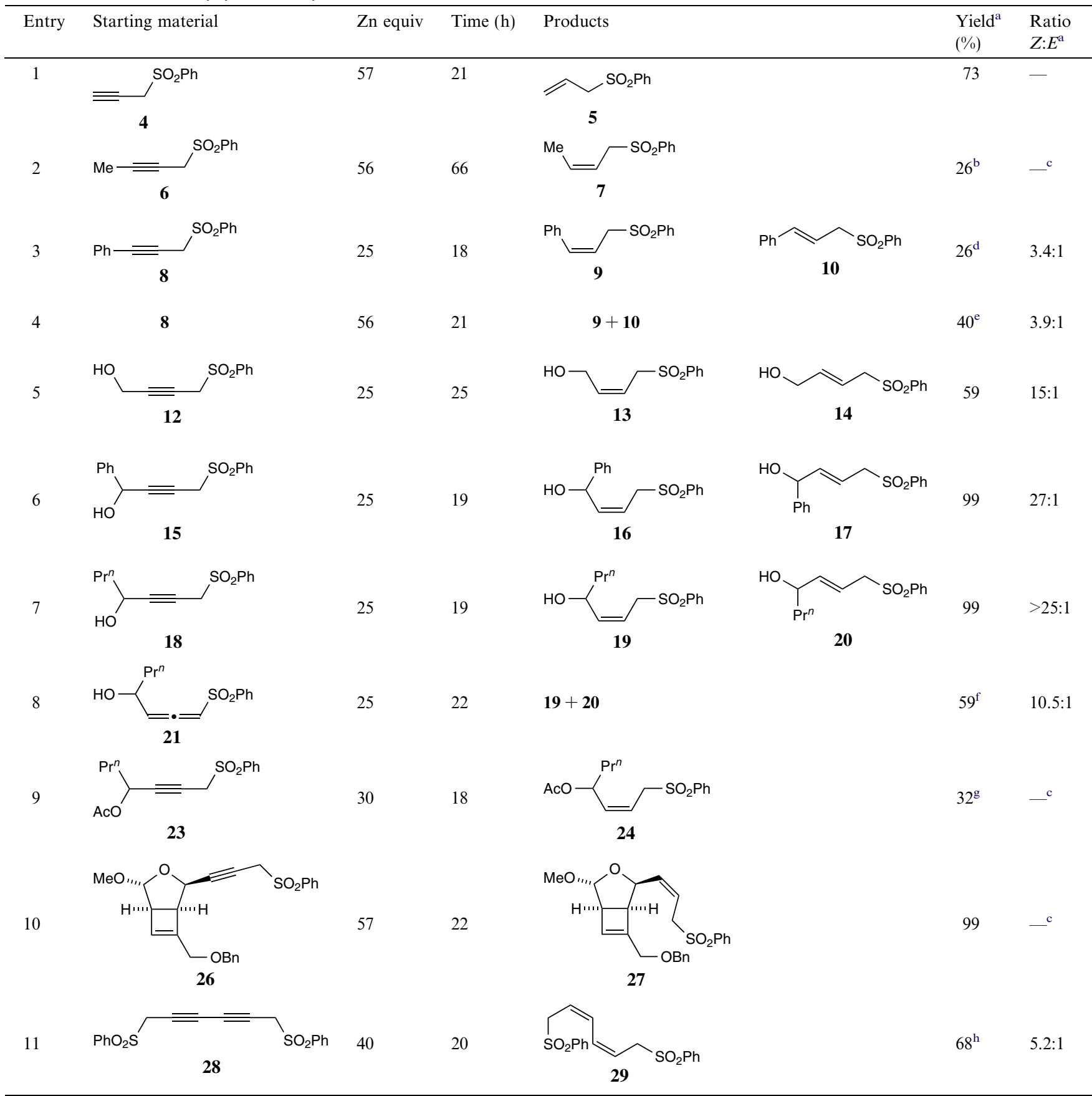

${ }^{\mathrm{a}}$ Based on the analysis of isolated products by ${ }^{1} \mathrm{H}$ NMR spectroscopy.

${ }^{\mathrm{b}}$ Also unreacted $6(70 \%)$.

${ }^{\mathrm{c}} E$-isomer not detected.

${ }^{\mathrm{d}}$ Also unreacted $\mathbf{8}(43 \%)$ and $\mathbf{1 1}(19 \%)$.

${ }^{\mathrm{e}}$ Also unreacted $\mathbf{8}(7 \%)$ and $\mathbf{1 1}(31 \%)$.

f Also 22 (5\%).

${ }^{\mathrm{g}}$ Also unreacted $23(25 \%)$ and $25(5 \%)$.

${ }^{\mathrm{h}}$ Major component of a complex mixture.<smiles>O=[Sb](/C=C/c1ccccc1)(Oc1ccccc1)c1ccccc1</smiles>

11<smiles>CCCC(O)CC=CCS(=O)(=O)c1ccccc1</smiles>

22<smiles>CCCC(C=C=CS(=O)(=O)c1ccccc1)C(C)=O</smiles> 


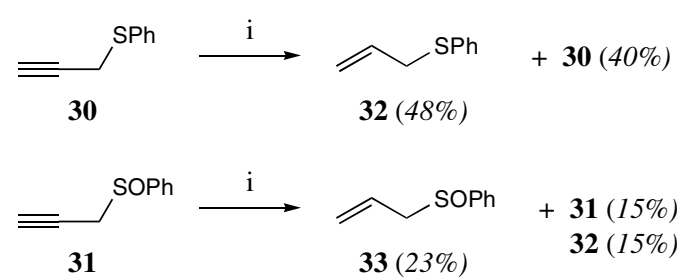

Scheme 2. Reagents and conditions: (i) $\mathrm{Zn}$ (25 equiv), $\mathrm{NH}_{4} \mathrm{Cl}, \mathrm{H}_{2} \mathrm{O}$, THF, $25^{\circ} \mathrm{C}$, ca. $24 \mathrm{~h}$.

NMR data and by comparison with related compounds discussed below. When the extra substituent incorporated a hydroxyl group adjacent to the alkyne bond (entries 5-7), both the efficiency and the $(Z)$-selectivity of the process dramatically improved, the transformations of 15 into 16 and of $\mathbf{1 8}$ into 19 being almost quantitative.

Other experiments provided additional insight into the scope and limitations of this reduction protocol. A sample of allenyl sulfone $\mathbf{2 1}$ was obtained from its alkynyl tautomer 18 and subjected to the standard reduction conditions (entry 8). Isomeric allylic sulfones 19 and 20 were once again obtained, with lower selectivity, along with a small quantity of the conjugated sulfone 22. With the acetylated system $\mathbf{2 3}$ (entry 9) the reaction was sluggish but the alkyne bond was once again hydrogenated selectively, and a small quantity of the corresponding allenyl sulfone $\mathbf{2 5}$ was observed. The potentially labile benzyloxy and cyclobutene components of sulfone 26 (entry 10) were both tolerant to the reaction conditions, with clean conversion to the highly functionalised sulfone $\mathbf{2 7}$ proving possible. A 'double' reduction of the conjugated diyne $\mathbf{2 8}$ was less effective, giving a product mixture in which the symmetrical $(Z, Z)$-diene $\mathbf{2 9}$ was tentatively identified as the major component (entry 11).

In recent studies on the use of zinc in alkyne reductions, Kaufman and coworkers ${ }^{16,21}$ emphasised the intriguing interplay of mechanistic possibilities, and in seeking to interpret our own results we carried out some additional experiments. Firstly, the reactivity of the parent sulfone 4 was compared with those of analogous thioether $\mathbf{3 0}$ and sulfoxide 31 (Scheme 2). Thioether $\mathbf{3 0}$ was reduced fairly cleanly to $\mathbf{3 2}$ but proved less reactive than the sulfone 4, with only $60 \%$ conversion after $24 \mathrm{~h}$. Under similar conditions sulfoxide $\mathbf{3 1}$ gave a more complex

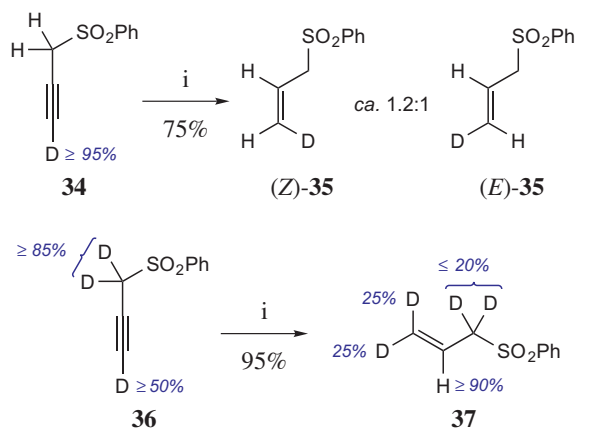

Scheme 3. Reagents and conditions: (i) $\mathrm{Zn}$ (5 equiv), $\mathrm{NH}_{4} \mathrm{Cl}, \mathrm{H}_{2} \mathrm{O}$, THF, $25^{\circ} \mathrm{C}, 23 \mathrm{~h}$.

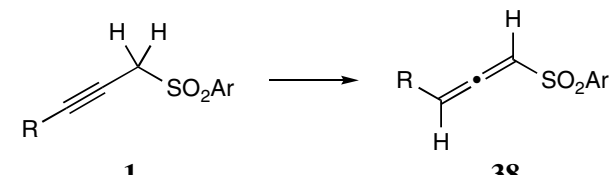

1

Scheme 4. Propargyl to allenyl isomerisation.

mixture containing only small amounts of the desired sulfoxide 34, together with unreacted starting material and the over-reduction product 32. Given that the partial hydrogenation of 1-decyne is relatively slow using sonication-activated electrodeposited zinc and aq ammonium chloride $\left(100^{\circ} \mathrm{C}, 16 \mathrm{~h}\right),{ }^{17}$ we surmise that for propargylic sulfones this type of reduction is strongly facilitated by coordination of the substrate to the zinc surface via the sulfone group. The transfer of an electron into the sulfur functional group, which is implicit in the formation of thioether $\mathbf{3 2}$ from sulfoxide $31,{ }^{22}$ could initiate such coordination. The presence of an oxygen substituent at the other end of the alkyne bond (Table 1, entries 5-7, 11) also appears to assist the reduction process, as discussed previously. ${ }^{15}$

The results of isotopic labelling experiments (Scheme 3) are consistent with the operation of mechanistically distinct routes to the observed products. The deuterium label at the terminal position of alkyne $\mathbf{3 4}$ was distributed almost evenly in the reduced product 35 , a result which contrasts sharply with the high $(Z)$-selectivity observed in the hydrogenation of many of the internal alkynes tested. With the triply-labelled substrate 36, much of the deuterium in the methylene group was lost in the course of the reduction, and given their involvement and viability as intermediates (Table 1, entries 3, 4 and $8-10$ ), we propose that allene formation partially accounts for this. The propargyl-to-allenyl isomerisation (Scheme 4) has been exploited in the development of a series of DNA-cleaving agents which operate in a $\mathrm{pH}$ dependent manner. ${ }^{23}$ The process is rapid under basic conditions and can be induced with alumina, ${ }^{24}$ but is inhibited by acid. ${ }^{25} \mathrm{We}$ speculate that this isomerisation, or its equivalent, is rendered possible by the heterogeneous conditions of the zinc/ammonium chloride reduction and/or the participation of partially reduced species.

In summary, propargylic sulfones can be cis-hydrogenated using commercial zinc powder and ammonium chloride in $\mathrm{THF}$-water at room temperature, the major products from internal alkynes being $(Z)$-allylic sulfones. The optimal substrates possess a potential coordination site in the second propargylic position, and other reducible groups (alkene, benzyloxy) are not affected. Allenylsulfones are implicated in one of the possible reaction pathways.

\section{Acknowledgement}

We thank the Engineering and Physical Sciences Research Council (EPSRC) for a postdoctoral research award (GR/S82671). 


\section{Supplementary data}

Preparative details for most of the starting materials in Table 1 and Schemes 2 and 3. Supplementary data associated with this article can be found, in the online version, at doi:10.1016/j.tetlet.2007.04.099.

\section{References and notes}

1. For a review of the Julia reaction, see: (a) Blakemore, P. R. J. Chem. Soc., Perkin Trans. 1 2002, 2563-2585; See also: (b) Shibayama, A.; Nakamura, T.; Asada, T.; Shintani, T.; Ukaji, Y.; Kinoshita, H.; Inomata, K. Bull. Chem. Soc. Jpn. 1997, 70, 381-396; (c) Phillips, E. D.; Warren, E. S.; Whitham, G. H. Tetrahedron 1997, 53, 307320; (d) Jeon, H.-S.; Yeo, J. E.; Jeong, Y. C.; Koo, S. Synthesis 2004, 2813-2820.

2. For examples, see: (a) Katritzky, A. R.; Piffl, M.; Lang, H.; Anders, E. Chem. Rev. 1999, 99, 665-722; (b) Ji, M.; Choi, H.; Jeong, Y. C.; Jin, J.; Baik, W.; Lee, S.; Kim, J. S.; Park, M.; Koo, S. Helv. Chim. Acta 2003, 86, 26202628; (c) Clayden, J.; Julia, M. J. Chem. Soc., Chem. Commun. 1994, 2261-2262.

3. (a) Nouguier, R.; Gastaldi, S.; Stien, D.; Bertrand, M.; Renaud, P. Tetrahedron Lett. 1999, 40, 3371-3374; (b) Van Dort, P. C.; Fuchs, P. L. J. Org. Chem. 1997, 62, 7137-7141, and references cited therein.

4. Díez, D.; García, P.; Fernández, P.; Marcos, I. S.; Garrido, N. M.; Basabe, P.; Broughton, H. B.; Urones, J. G. Synlett 2005, 158-160.

5. (a) Hirata, T.; Sasada, Y.; Ohtani, T.; Asada, T.; Kinoshita, H.; Senda, H.; Inomata, K. Bull. Chem. Soc. Jpn. 1992, 65, 75-96; (b) Cossu, S.; Peluso, P.; Moretto, F.; Marchetti, M. Tetrahedron Lett. 2006, 47, 2253-2256.

6. Yamazaki, M.; Guha, S. K.; Ukaji, Y.; Inomata, K. Chem. Lett. 2006, 35, 514-515.

7. (a) Sun, P.; Wang, L.; Zhang, Y. Tetrahedron Lett. 1997, 38, 5549-5550; (b) Martin, D. D.; San Feliciano, S. G.; Marcos, I. S.; Basabe, P.; Garrido, N. M.; Urones, J. G. Synthesis 2001, 1069-1075; (c) Baruah, M.; Boruah, A.; Prajapati, D.; Sandhu, J. S. Synlett 1998, 1083-1084.

8. Sha, F.; Wu, Z.; Huang, X. Synth. Commun. 2006, 36, 2603-2612.

9. (a) Jagusch, T.; Gais, H.-J.; Bondarev, O. J. Org. Chem. 2004, 69, 2731-2736; (b) Jung, S.-Y.; Min, J.-H.; Oh, J. T.; Koo, S. J. Org. Chem. 2006, 71, 4823-4828.

10. Bonini, C.; Chiummiento, L.; Videtta, V. Synlett 2005, 3067-3070.

11. (a) Ozawa, M.; Iwata, N.; Kinoshita, H.; Inomata, K. Chem. Lett. 1990, 1689-1692; (b) Iwata, N.; Morioka, T.; Kobayashi, T.; Asada, T.; Kinoshita, H.; Inomata, K. Bull. Chem. Soc. Jpn. 1992, 65, 1379-1388.

12. Thyagarajan, B. S.; Chandler, R.; Santillan, A. Synth. Commun. 1990, 20, 3477-3488.

13. Sondengam, B. L.; Charles, G.; Akam, T. M. Tetrahedron Lett. 1980, 21, 1069-1070.

14. Aerssens, M. H. P. J.; Brandsma, L. J. Chem. Soc., Chem. Commun. 1984, 735-736.

15. Chou, W.-N.; Clark, D. L.; White, J. B. Tetrahedron Lett. 1991, 32, 299-302.

16. Kroemer, J.; Kirkpatrick, C.; Maricle, B.; Gawrych, R.; Mosher, M. D.; Kaufman, D. Tetrahedron Lett. 2006, 47, 6339-6341.

17. Durant, A.; Delplancke, J. L.; Libert, V.; Reisse, J. Eur. J. Org. Chem. 1999, 2845-2851.

18. The zinc used was 'nanosize activated powder' (Aldrich 578002).
19. Typical procedure (entry 7): To a stirred solution of sulfone $18(25 \mathrm{mg}, 0.10 \mathrm{mmol})$ in THF $(1.9 \mathrm{~mL})$ at room temperature was added zinc powder $(161 \mathrm{mg}, 2.46 \mathrm{mmol})$ followed by saturated aq ammonium chloride $(1.9 \mathrm{~mL})$. The resulting mixture was vigorously stirred for $19 \mathrm{~h}$, diluted with water $(10 \mathrm{~mL})$ and extracted with EtOAc $(3 \times 3 \mathrm{~mL})$. The combined extract was dried $\left(\mathrm{MgSO}_{4}\right)$, filtered and concentrated in vacuo. Flash chromatography of the residue, eluting with EtOAc-hexane (3:7), yielded a mixture of 19 and $20(25 \mathrm{mg}, 99 \%)$ as a colourless oil. The products were often sufficiently pure for use without chromatography.

20. All compounds are racemic and new compounds gave satisfactory analytical data. Most entries refer to a single experiment using standard conditions. Characterising data (unless stated, all NMR spectra at $400 \mathrm{MHz}$ in $\mathrm{CDCl}_{3}$ ): Compound 5, $\delta_{\mathrm{H}} 5.77(1 \mathrm{H}, \mathrm{tdd}, J 7.3,10.0,17.1 \mathrm{~Hz}, 2-\mathrm{H})$, $5.32(1 \mathrm{H}, \mathrm{d}, J 10.0 \mathrm{~Hz}, 3-\mathrm{H}), 5.13(1 \mathrm{H}, \mathrm{d}, J 17.1 \mathrm{~Hz}, 3-\mathrm{H})$, $3.81\left(2 \mathrm{H}, \mathrm{d}, J 7.3 \mathrm{~Hz}, 1-\mathrm{H}_{2}\right)$; Compound $7, \delta_{\mathrm{H}}(300 \mathrm{MHz})$ $5.82(1 \mathrm{H}, \mathrm{qd}, J 7.0,10.5 \mathrm{~Hz}, 3-\mathrm{H}), 5.43(1 \mathrm{H}, \mathrm{qtd}, J 1.5,7.5$, $10.5 \mathrm{~Hz}, 2-\mathrm{H}), 3.85(2 \mathrm{H}, \mathrm{d}, J 7.5 \mathrm{~Hz}, 1-\mathrm{H}), 1.33(1 \mathrm{H}, \mathrm{dd}, J$ $1.5,7.0 \mathrm{~Hz}, 5-\mathrm{H})$; Compound $9, \delta_{\mathrm{H}} 6.80(1 \mathrm{H}$, br d, $J$ $11.5 \mathrm{~Hz}, 3-\mathrm{H}), 5.72(1 \mathrm{H}, \mathrm{td}, J 8.0,11.5 \mathrm{~Hz}, 2-\mathrm{H}), 4.06(2 \mathrm{H}$, $\left.\mathrm{dd}, J 1.5,8.0 \mathrm{~Hz}, 1-\mathrm{H}_{2}\right)$; Compound 10, $\delta_{\mathrm{H}} 6.37(1 \mathrm{H}$, br d, $J$ $15.9 \mathrm{~Hz}, 3-\mathrm{H}), 6.10(1 \mathrm{H}, \mathrm{td}, J 7.5,15.9 \mathrm{~Hz}, 2-\mathrm{H}), 3.96(2 \mathrm{H}$, $\left.\mathrm{dd}, J 1.0,7.5 \mathrm{~Hz}, 1-\mathrm{H}_{2}\right)$; Compound 11, $\delta_{\mathrm{H}} 6.95-7.00(2 \mathrm{H}$, $\mathrm{m})$; Compound 13, $\delta_{\mathrm{H}} 6.06(1 \mathrm{H}, \mathrm{ttd}, J 1.0,6.5,11.0 \mathrm{~Hz}, 2-$ $\mathrm{H}), 5.48(1 \mathrm{H}, \mathrm{ttd}, J 1.5,8.0,11.0 \mathrm{~Hz}, 3-\mathrm{H}), 4.06(2 \mathrm{H}, \mathrm{dd}, J$ $\left.1.5,6.5 \mathrm{~Hz}, 1-\mathrm{H}_{2}\right), 3.98\left(2 \mathrm{H}, \mathrm{dd}, J 1.0,8.0 \mathrm{~Hz}, 4-\mathrm{H}_{2}\right)$; Compound 14, $\delta_{\mathrm{H}} 5.8-5.6(2 \mathrm{H}, \mathrm{m}, 2-\mathrm{H}$ and $3-\mathrm{H}), 4.11(2 \mathrm{H}$, br d, $\left.J 4.5 \mathrm{~Hz}, 1-\mathrm{H}_{2}\right), 3.80\left(2 \mathrm{H}\right.$, br d, $\left.J 6.5 \mathrm{~Hz}, 4-\mathrm{H}_{2}\right)$ Compound 16, $\delta_{\mathrm{H}}(300 \mathrm{MHz}) 6.05(1 \mathrm{H}, \mathrm{dd}, J 8.1,10.5 \mathrm{~Hz}$, 2-H), 5.52 (1H, ddd, $J 7.9,8.7,10.5 \mathrm{~Hz}, 3-\mathrm{H}), 5.36(1 \mathrm{H}, \mathrm{d}, J$ $8.1 \mathrm{~Hz}, 1-\mathrm{H}), 4.19(1 \mathrm{H}, \mathrm{dd}, J 8.7,13.9 \mathrm{~Hz}, 4-\mathrm{H}), 4.03(1 \mathrm{H}$, dd, $J 7.9,13.9 \mathrm{~Hz}, 4-\mathrm{H})$; Compound 17, $\delta_{\mathrm{H}}(300 \mathrm{MHz}) 5.84$ $(1 \mathrm{H}$, ddd, $J 9.0,10.5,16.1 \mathrm{~Hz}, 3-\mathrm{H}), 5.73(1 \mathrm{H}, \mathrm{dd}, J 5.5$, $16.1 \mathrm{~Hz}, 2-\mathrm{H})$; Compound $19, \delta_{\mathrm{H}} 5.84(1 \mathrm{H}, \mathrm{dd}, J 8.5$, $10.8 \mathrm{~Hz}, 3-\mathrm{H}), 5.41(1 \mathrm{H}$, ddd, $J 7.5,8.5,10.7 \mathrm{~Hz}, 2-\mathrm{H}), 4.22$ $(1 \mathrm{H}$, br td, $J 7.0,8.5 \mathrm{~Hz}, 4-\mathrm{H}), 4.05(1 \mathrm{H}, \mathrm{ddd}, J 1.0,8.5$, $13.8 \mathrm{~Hz}, 1-\mathrm{H}), 3.91(1 \mathrm{H}, \mathrm{dd}, J 7.5,13.8 \mathrm{~Hz}, 1-\mathrm{H})$; Compound 20, $\delta_{\mathrm{H}} 5.62(1 \mathrm{H}, \mathrm{td}, J 7.0,15.5 \mathrm{~Hz}, 2-\mathrm{H}), 5.56$ $(1 \mathrm{H}, \mathrm{dd}, J 5.5,15.5 \mathrm{~Hz}, 3-\mathrm{H}), 3.79\left(2 \mathrm{H}, \mathrm{d}, J 7.0 \mathrm{~Hz}, 1-\mathrm{H}_{2}\right)$ Compound 22, $\delta_{\mathrm{H}} 7.03(1 \mathrm{H}, \mathrm{td}, J 7.5,15.1 \mathrm{~Hz}, 2-\mathrm{H}), 6.41$ $(1 \mathrm{H}, \mathrm{td}, J 1.5,15.1 \mathrm{~Hz}, 1-\mathrm{H}), 2.41$ (1H, dddd, $J 1.5,4.0,7.0$, $14.7 \mathrm{~Hz}, 3-\mathrm{H}), 2.32(1 \mathrm{H}, \mathrm{dtd}, J 1.0,7.5,14.7 \mathrm{~Hz}, 3-\mathrm{H})$; Compound $24, \delta_{\mathrm{H}} 5.67-5.57\left(2 \mathrm{H}, \mathrm{m}, J_{2,3} 11.0 \mathrm{~Hz}, 2-\mathrm{H}\right.$ and $3-\mathrm{H}), 5.15(1 \mathrm{H}, \mathrm{dt}, J 4.5,8.5 \mathrm{~Hz}, 4-\mathrm{H}), 4.25(1 \mathrm{H}, \mathrm{dd}, J 8.0$, $14.1 \mathrm{~Hz}, 1-\mathrm{H}), 3.89(1 \mathrm{H}, \mathrm{dd}, J 5.0,14.1 \mathrm{~Hz}, 1-\mathrm{H})$; Compound $25, \delta_{\mathrm{H}} 6.37\left(0.53 \mathrm{H}, \mathrm{dd}, J 2.0,6.0 \mathrm{~Hz}, 1-\mathrm{H}_{\mathrm{A}}\right)$, $6.32\left(0.47 \mathrm{H}, \mathrm{dd}, J 2.5,6.0 \mathrm{~Hz}, 1-\mathrm{H}_{\mathrm{B}}\right), 5.91(0.47 \mathrm{H}, \mathrm{t}, J$ $\left.6.0 \mathrm{~Hz}, 3-\mathrm{H}_{\mathrm{B}}\right), 5.87\left(0.53 \mathrm{H}, \mathrm{t}, J 6.0 \mathrm{~Hz}, 3-\mathrm{H}_{\mathrm{A}}\right)(\mathrm{A}, \mathrm{B}$ diastereoisomers); Compound 29, $\delta_{\mathrm{H}} 5.97(1 \mathrm{H}, \mathrm{s}, 7-\mathrm{H})$, $5.81\left(1 \mathrm{H}, \mathrm{dd}, J 6.3,10.3,1^{\prime}-\mathrm{H}\right), 5.53(1 \mathrm{H}, \mathrm{td}, J 8.8,10.3 \mathrm{~Hz}$, $\left.2^{\prime}-\mathrm{H}\right), 4.69(1 \mathrm{H}, \mathrm{s}, 2-\mathrm{H}), 4.28(1 \mathrm{H}, \mathrm{t}, J 6.3 \mathrm{~Hz}, 4-\mathrm{H}), 4.05$ $\left(1 \mathrm{H}, \mathrm{dd}, J 8.8,14.1 \mathrm{~Hz}, 3^{\prime}-\mathrm{H}\right), 3.97-3.87\left(1 \mathrm{H}, \mathrm{m}, 3^{\prime}-\mathrm{H}\right)$; Compound 31, $\delta_{\mathrm{H}} 6.20(2 \mathrm{H}, \mathrm{d}, J 9.0 \mathrm{~Hz}, 3,4-\mathrm{H}), 5.44(2 \mathrm{H}$, td, $J 8.0,9.0 \mathrm{~Hz}, 2,5-\mathrm{H}), 3.89(4 \mathrm{H}, \mathrm{d}, J 8.0 \mathrm{~Hz}, 1,6-\mathrm{H})$.

21. Kaufman, D.; Johnson, E.; Mosher, M. D. Tetrahedron Lett. 2005, 46, 5613-5615.

22. For a discussion, see: Chellammal, S.; Noel, M.; Anantharaman, P. N. J. Chem. Soc., Perkin Trans. 2 1993, 993 997.

23. (a) Nicolaou, K. C.; Skokotas, G.; Maligres, P.; Zuccarello, G.; Schweiger, E. J.; Toshima, K.; Wendeborn, S. Angew. Chem., Int. Ed. Engl. 1989, 28, 1272-1275; (b) Nicolaou, K. C.; Wendeborn, S.; Maligres, P.; Isshiki, K.; Zein, N.; Ellestad, G. Angew. Chem., Int. Ed. Engl. 1991, 30, 418-420; (c) Braverman, S.; Zafrani, Y.; Gottlieb, H. E. Tetrahedron 2001, 57, 9177-9185; (d) Haruna, K.; 
Kanezaki, H.; Tanabe, K.; Dai, W.-M.; Nishimoto, S. Bioorg. Med. Chem. 2006, 14, 4427-4432, and references cited therein.

24. (a) Stirling, C. J. M. J. Chem. Soc. 1964, 5863-5869; (b) Pourcelot, G.; Cadiot, P. Bull. Soc. Chim. Fr. 1966, 30243033; (c) VanZanten, A.; Mullaugh, K.; Harrington, R.;
Kiefer, A.; Carlson, D.; Mastarone, D.; Lipchik, C.; Murphree, S. S. Synthesis 2004, 2611-2613; for a pertinent review, see: (d) Back, T. G. Tetrahedron 2001, 57, 52635301.

25. For an example, see: Sakai, Y.; Bando, Y.; Shishido, K.; Shibuya, M. Tetrahedron Lett. 1992, 33, 957-960. 